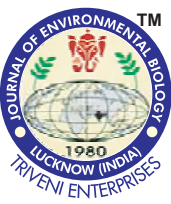

DOI : http://doi.org/10.22438/jeb/39/3/MRN-593

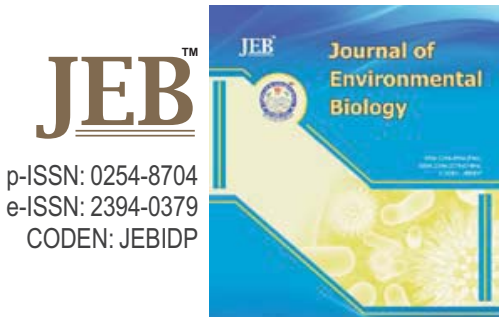

\title{
A five years study on the selection of rice based cropping systems in Goa, for west coast region of India
}

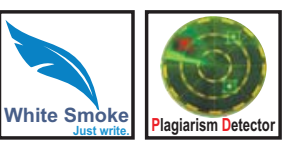

Authors Info

B.L. Manjunath', V. Paramesh ${ }^{2 *}$, G.R. Mahajan', K.V. Reddy ${ }^{2}$, B. Das ${ }^{2}$ and N.P. Singh

'NRM Section, ICAR-Indian Institute of Horticultural Research, Bengaluru-560 089, India

${ }^{2}$ NRM Section, ICAR- Central Coastal Agricultural Research Institute, Goa-403 402, India

${ }^{3}$ NRM Section, ICAR- National Institute of Abiotic Stress

Management,

Baramati-413 115, India

*Corresponding Author Email : parameshagron@gmail.com

Key words

Cropping system

Economic analysis

Energy ratio

Nutrient balance

Residue recycling

Publication Info

Paper received : 18.02 .2017

Revised received : 03.06.2017

Re-revised received : 04.08.2017

Accepted : 26.09.2017

\section{Abstract}

Aim : Field experiments were conducted for five years during 2010-11 to 2014-15 to select productive and profitable rice based cropping systems for West coast region of India at ICAR-Central Coastal Agricultural Research Institute, Goa.

Methodology : Cropping systems viz. rice-cowpea, rice-groundnut, rice-brinjal and rice-sweet corn were tested for their production potential, economic feasibility, nutrient balance and energy budgeting along with rice-fallow as control.

Results : The data indicated significantly higher rice equivalent yield $\left(23.5 \mathrm{t} \mathrm{ha}^{-1}\right)$ with rice-sweet corn followed by rice-brinjal $\left(14.1 \mathrm{t} \mathrm{ha}^{-1}\right)$ as compared to a predominant rice-fallow system of the region $\left(5.50\right.$ tha $\left.^{-1}\right)$. Higher potential usable residue was also found higher with rice- sweet corn system ( 36.9 tha $\left.^{-1}\right)$. Results of the energy ratio (46.5), specific energy $\left(0.65 \mathrm{MJ} \mathrm{kg}^{-1}\right)$ and energy productivity $\left(1.52 \mathrm{~kg} \mathrm{MJ}^{-1}\right)$ indicate that the rice-sweet corn is most energy efficient system among all the evaluated systems. Although, rice-brinjal system depicted higher onfarm employment potential (217 man days ha ${ }^{-1}$ year $\left.{ }^{-1}\right)$ with an increase of $317 \%$ over monocropping, while the economic analysis indicted higher net return ( $\square .95350)$ and benefit cost ratio (2.57) in rice-sweet corn system. The nutrient balance were positive for $\mathrm{N}$ and $\mathrm{P}$, while in all the cropping systems the K balance was found negative.

Interpretation : The rice-sweet corn system was found to be the most productive, economical and energy efficient cropping system for the West coast region of India under protective irrigated conditions.

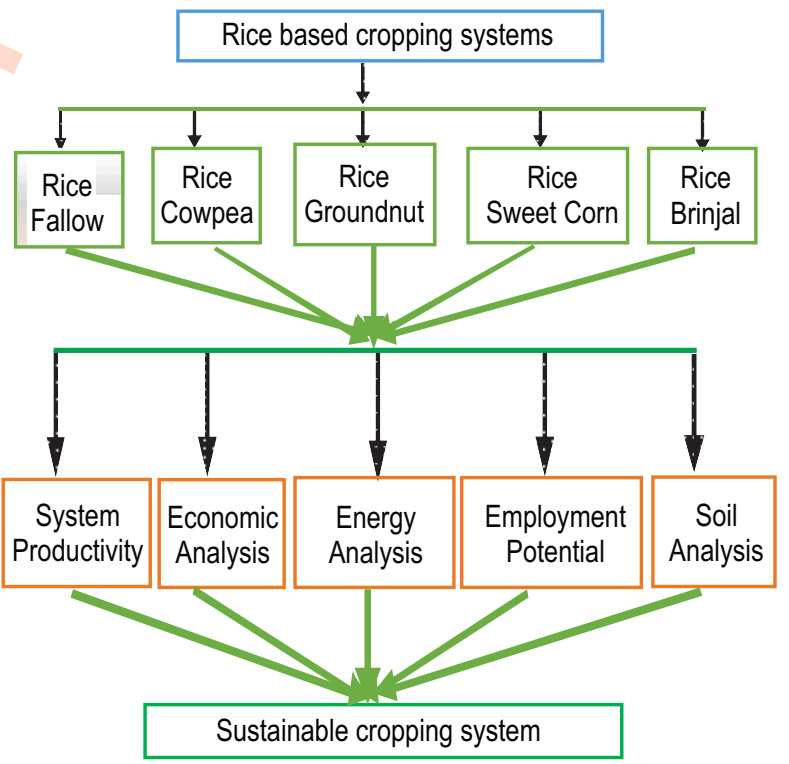




\section{Introduction}

West coast plains and Ghats region of India has a warm humid tropical climate with mean annual rainfall of $280 \mathrm{~cm}$. The main crops of the region include rice, sugarcane, cowpea, groundnut, plantation crops and spices. The operational land holdings in this region are highly fragmented with more than $80 \%$ of the holdings are less than one hectare (Korikanthimath and Manjunath, 2009). The undulating topography coupled with high rainfall during Kharif and flooding by drained water from uplands making rice as most suitable crop for this region. Majority farmers take up single crop of rice leaving the land fallow during rabi although these lowlands have a huge potential to grow rabi crops due to adequate residual soil moisture after rice harvest. Further, in the recent years, rice production is under threat in the region owing to increased cost of cultivation (Manjunath et al., 2010). Crop diversification is imperative for this region to achieve food and nutritional security. This could be achieved by increasing the cropping intensity by growing less exhaustive, water efficient and fertility restoring crops like vegetables, oilseeds and pulses (Hegde et al., 2003; Gill and Ahlawat, 2006; Kankwamba et al., 2012).

In this region, cropping systems like rice-cowpea, ricegroundnut and rice-vegetables are followed to a limited extent under rice fallows. Earlier studies in this direction have clearly brought out the feasibility of rice-brinjal cropping system under protective irrigated situations (Manjunath and Korikanthimah, 2004). For residual moisture situations, substituted crop must be of short duration, tolerant to terminal water stress, better yielding, disease and pest resistant having a quick ground cover with high local market demand. The crop should be with good acceptance by the local farmers for their capacity to adjust to existing cropping system and it should improve the long-term productivity and profitability of the system (Sharma et al., 2014). Cowpea, groundnut, brinjal and sweet corns are the potential crops for this region (Manjunath et al., 2010).

Further, production of adequate biomass and returning sizeable portion of it is imperative for maintaining the soil productivity of the whole cropping system. Otherwise, the systems can be over exploitative like the mono-cropping leading to disturbance in the biological activities and loss of nutrients and soil health. The productivity of the system can be improved by recycling of these potentially usable residues and there is greater employment for the most part of the year. Further, the problems of energy consumption, shortage and environmental pollution have created an urge for processing organics for energy and plant nutrient recovery (Manjunath and Itnal, 2005). Thus, considering the above facts an attempt was made to asses different cropping systems on production, productivity, economics and employment potential; determine the energy efficient cropping system for lowland situation and study the effect of cropping systems on soil chemical properties.

\section{Materials and Methods}

Experimental location : The experiment was carried out at ICAR-Central Coastal Agricultural Research Institute, Goa, India during the period 2010-11 to 2014-15. The region has a warm humid tropical climate. The rice crop received an adequate amount of rainfall (five year's average- $3180 \mathrm{~mm}$ ) for crop growth. During rice crop growing period (June to October), a total of 3128 , $3490,2890,3248$ and $3093 \mathrm{~mm}$ rainfall was received in the first, second, third, fourth and fifth year of study, respectively. During rabi season the rainfall was meager. Cowpea and groundnut were grown on limited irrigation condition, while brinjal and sweet corn were grown under protective irrigated conditions as per local practice.

Experimental design and treatments : Five cropping system treatments studied differed from one another with respect to crop management practices. The study was done in an area of 0.4 ha and identical area was assigned for each cropping system. Rice (variety Karjat-3) based crops suitable to the region were designed for the experiments. The cropping systems studied were rice-fallow, rice-cowpea (var. Goa cowpea-3), ricegroundnut (var. TG-51), rice-brinjal (var. local selection Aggasaim) and rice-sweet corn (var. S-75). All the recommended practices were followed as per crop needs. The rice-fallow treatment was considered to assess the economic losses due to fallowing which is quite common in the study region. The recycled manure was applied uniformly to the entire experimental field before one month of rice transplanting and pulverized to a depth of $0.3 \mathrm{~m}$ by ploughing and harrowing. The leaf litter and root residue were incorporated in situ after the crop harvest. Rice crop was transplanted in the month of July and harvested in October month. The sowing of the cowpea, groundnut and sweet corn was done during the second fortnight of November to first fortnight of December based on the available residual soil moisture. The brinjal was also transplanted during the same time.

Soil sampling and chemical analysis : The initial and final soil sample was collected from 0-30 cm soil depth. The composite soil sample was air-dried, powdered and sieved through $2 \mathrm{~mm}$ sieve for further chemical analysis. The experimental soil had $\mathrm{pH}$ 6.01, electrical conductivity (EC) $0.02 \mathrm{dS} \mathrm{m}^{-1}$, bulk density $1.34 \mathrm{mg} \mathrm{m}^{-3}$, soil available nitrogen (N) $155 \mathrm{~kg} \mathrm{ha}^{-1}$ (Subbiah and Asija, 1956), soil available phosphorus (P) $21.1 \mathrm{~kg} \mathrm{ha}^{-1}$ (Bray and Kurtz,1945) and soil available potassium (K) $188 \mathrm{~kg} \mathrm{ha}^{-1}$ (Hanway and Heidel, 1952).

Crop yield estimation : Grain and straw yields of rice, grain and pod/seed yields of cowpea and groundnut, cob yield of sweet corn and brinjal fruit yields were determined manually. The data of five replicate measurements ( $1 \mathrm{~m}^{2}$ each) from each of the plot was recorded. The grain yields of rice, cowpea and groundnut were adjusted to 14,12 and $20 \%$ moisture content, respectively. In the case of brinjal, harvesting was done batch wise and the yields 
were recorded as the weight of fruits. The sweet corn cobs were harvested batch wise and the yield data was recorded as number of cobs. For calculating rice equivalent yield (REY), the farm-gate prices of different produce prevailing in local market were considered. The REY was computed using the formulae of Anjaneyulu et al. (1982).

Potential usable residue : The recyclable wastes used as manure to enrich soil fertility in both rice and rice-based crops, were quantified periodically as potential usable residue and expressed as tons per hectare.

Energy calculation : The energy equivalent was calculated for each farm input (labour, machinery use, seeds, fertilizers, pesticides, fuel, irrigation and electricity) and output (economic yield of different crops, crop residues, etc.) by multiplying a respective energy value. Fuel consumption during land preparation, transplanting, harvesting, etc. was recorded. All the energy indices were calculated using the equations of Rafiee et al. (2010).

Employment potential : Labour required for various activities of crop production were recorded and given in man-days ha ${ }^{-1}$ year ${ }^{-1}$. A man or woman working for eight hours a day was considered as one man-day.

Economic analysis : The total variable costs of production and gross returns were computed for economic analysis. The cost of production includes human labour, tractor rent, input costs (seed, fertilizer, pesticides, fuel and electricity) etc. The costs of different inputs like seeds, fertilizers, pesticides and fuel were calculated based on the market prices during the period. Gross return were obtained by multiplying economic yields and market price. Net returns were estimated by subtracting the cost of production with gross return. The benefit-cost ratio (BCR) was calculated by dividing the cost of production by gross return.

Data analysis : In the present investigation, the replicated data was collected from different plots as the plots were not replicated due to fixed experimental design. Data were subjected to analysis of variance (ANOVA) using the Statistical Analysis System (SAS Institute, 2014). The critical difference test at $5 \%$ significance level was used to test the differences between the system means.

\section{Results and Discussion}

A significantly higher rice grain yield was recorded in ricegroundnut $\left(5.47 \mathrm{t} \mathrm{ha}^{-1}\right)$ followed by rice-cowpea and rice-fallow (both $5.43 \mathrm{t} \mathrm{ha}^{-1}$ ) systems. Rice-sweet corn (5.20 tha $\left.\mathrm{t}^{-1}\right)$ and ricebrinjal (5.23 t ha-1) recorded relatively lower rice grain yield (Table 1). The improvement in rice yield in rice-groundnut and ricecowpea might be due to beneficial effect of legume crops on soil fertility. Biological nitrogen fixation and addition of biomass improves soil physical conditions and availability of nitrogen (Knoth et al., 2014). Pokhrel and Pokhrel (2013) reported that legume crops provide 15 tha ${ }^{-1}$ biomass and quick decomposition of crop residues release available nutrients to produce additional grain yield in the rice-legume rotation, whereas decrease in rice yields under both rice-sweet corn and rice-brinjal system could be attributed to the nutrient exhaustive nature of both the rabi crops. This nature of sweet corn and brinjal makes the soil less productive for the successive crops (Singh et al. 2011). Kannan et al. (2013) reported that inclusion of exhaustive crop such as maize will remove more available nutrients from the soil as compared to legumes and also reduce the microbial activity in the soil.

The REY in different cropping systems differed significantly (Table 1). Pooled analysis of five years data indicated that the highest REY (23.5 tha ${ }^{-1}$ ) and system productivity (110.8 $\mathrm{kg} \mathrm{ha}^{-1}$ day $^{-1}$ ) were recorded with rice-sweet corn, followed by ricebrinjal system ( $14.1 \mathrm{t} \mathrm{ha}^{-1}$ and $51.1 \mathrm{~kg} \mathrm{ha}^{-1}$ day $\left.^{-1}\right)$. The average duration of the cropping systems showed noticeable differences over the five-years. The rice-sweet corn system took average minimum duration for production (212 days) as compared to other systems because sweet corn was harvested for green cobs. On the contrary, the rice-brinjal system with second highest REY took comparatively higher duration ( 275 days). The higher equivalent yield and system productivity of rice-sweet corn system was due to higher yield potential, market price and efficient utilization of time and space (Ramachandra et al., 2007; Choudhary et al., 2000). The system with short duration and high production should be preferred for commercial cultivation to increase equivalent yield and system productivity (Brahmanand et al., 2009; Basak et al., 2016).

The total biomass production was significantly influenced by different cropping systems (Table 2). Among the cropping systems studied, rice-sweet corn system recorded more biomass production $\left(61.6 \mathrm{t} \mathrm{ha}^{-1}\right)$ followed by rice-brinjal $\left(33.4 \mathrm{t} \mathrm{ha}^{-1}\right)$. The rice-sweet corn system recorded $572.9 \%$ higher total biomass over rice-fallow system ( $\left.9.16 \mathrm{t} \mathrm{ha}^{-1}\right)$. The higher biomass in the treatment was due to the fast-growing nature of the sweet corn hybrid. The potential usable residue followed a similar trend as that of total biomass production. The higher potential usable residue was observed with rice-sweet corn system ( $36.92 \mathrm{t} \mathrm{ha}^{-1}$ ) which differed significantly and recorded $466.3 \%$ higher compared to rice-fallow system $\left(6.52 \mathrm{t} \mathrm{ha}^{-1}\right)$. Although rice-brinjal system recorded substantial total biomass, the potential usable residue $\left(6.52 \mathrm{t} \mathrm{ha}^{-1}\right)$ available from the system was negligible (Table 2). The nature of the biomass produced and suitability of the sweet corn hybrid to the region will result in higher availability of residue for recycling through composting. Earlier in the same agro climatic conditions, higher potential usable residue was noted in rice-sunn hemp system which resulted in production of good quality vermicompost having a mean nutrient content of $0.90 \% \mathrm{~N}, 0.27 \% \mathrm{P}$ and $0.13 \% \mathrm{~K}$ (Manjunath and Korikanthimath, 2009). 
The energy analysis of different cropping systems in the present investigation are depicted in Table 3. Total energy input and output was lower in rice-fallow system (15682 and 79115 MJ ha ${ }^{-1}$ ) compared to all other cropping systems. The ricebrinjal was found to be highly energy intensive with total energy input of $38332 \mathrm{MJ} \mathrm{ha}^{-1}$. On the contrary, the energy input of ricesweet corn was lesser but with higher energy output (1082858 MJ ha $\left.{ }^{-1}\right)$. The energy use efficiency followed the order rice-sweet corn (46.5) > rice - brinjal (7.88) > rice fallow (5.04) $>$ rice-cowpea (4.89) > rice-groundnut (4.84). Specific energy and energy productivity determined the energy efficiency of a production system and were reciprocal to each other. Lower specific energy $\left(0.65 \mathrm{MJ} \mathrm{kg}^{-1}\right)$ and higher energy productivity $\left(1.52 \mathrm{~kg} \mathrm{MJ}^{-1}\right)$ in rice-sweet corn indicated the potential of this cropping system to use energy efficiently as compared to other systems under investigation. Based on the energy productivity, the efficiency of different cropping system under study were found in the following order: rice-sweet corn $>$ rice-brinjal $>$ ricegroundnut $>$ rice-cowpea $>$ rice fallow. The trend of the net energy was more or less similar to energy productivity with the highest net energy of $1059577 \mathrm{MJ} \mathrm{ha}^{-1}$ in rice-sweet corn system.

Table 1 : Crop yield and system productivity of different cropping systems under lowland situations of Goa (pooled mean of five years)

\begin{tabular}{|c|c|c|c|c|c|}
\hline \multirow[t]{2}{*}{ Cropping systems } & \multicolumn{2}{|c|}{$\begin{array}{c}\text { Crop yield } \\
\left(\mathrm{t} \mathrm{ha}^{-1}\right)\end{array}$} & \multirow[t]{2}{*}{$\begin{array}{l}\text { REY* }^{*} \\
\left(\mathrm{t} \mathrm{ha}^{-1}\right)\end{array}$} & \multirow[t]{2}{*}{$\begin{array}{l}\text { Duration } \\
\text { (days) }\end{array}$} & \multirow{2}{*}{$\begin{array}{l}\text { System } \\
\text { productivity } \\
\left(\mathrm{kg} \mathrm{ha}^{-1} \text { day }^{-1}\right)\end{array}$} \\
\hline & Kharif & Rabi & & & \\
\hline Rice-fallow & 5.43 & - & 5.43 & 132 & 41.7 \\
\hline Rice-cowpea & 5.43 & 0.86 & 9.71 & 237 & 41.0 \\
\hline Rice-groundnut & 5.47 & 1.40 & 8.97 & 257 & 34.9 \\
\hline Rice-brinjal & 5.23 & 14.11 & 14.05 & 275 & 51.1 \\
\hline Rice-sweet corn & 5.20 & 9.76 & 23.49 & 212 & 110.8 \\
\hline S.Em \pm & 0.046 & & 3.11 & & 13.9 \\
\hline C.D $(P=0.05)$ & 0.14 & & 9.69 & & 43.2 \\
\hline
\end{tabular}

*REY- Rice equivalent yield

Table 2 : Total biomass production and the potential usable residue $\left(\mathrm{t} \mathrm{ha}{ }^{-1}\right.$ ) from different cropping systems under lowland situations of Goa (pooled mean of five years)

\begin{tabular}{lllll}
\hline Cropping systems & $\begin{array}{l}\text { Mean total biomass } \\
\text { production }\left(\mathrm{t} \mathrm{ha}^{-1}\right)^{* *}\end{array}$ & $\begin{array}{l}\text { Mean potential usable } \\
\text { residue }\left(\mathrm{t} \mathrm{ha}^{-1}\right)^{\star *}\end{array}$ & $\begin{array}{l}\text { Recyclable residue } \\
(\%)\end{array}$ & $\begin{array}{l}\text { Increase in potential } \\
\text { residue over rice-fallow } \\
\text { system }(\%)\end{array}$ \\
\hline Rice- fallow & 9.16 & 6.52 & 71.2 & -- \\
Rice- cowpea & 11.7 & 7.09 & 60.8 & 8.74 \\
Rice- groundnut & 17.5 & 10.8 & 61.9 & 66.0 \\
Rice- brinjal & 33.4 & 6.52 & 19.5 & - \\
Rice- sweet corn & 61.6 & $36.9^{*}$ & 59.9 & 466.3 \\
S.Em \pm & 1.12 & 0.80 & 8.7 & \\
C.D $(\mathrm{P}=0.05)$ & 3.50 & 2.50 & 27.3 & \\
\hline
\end{tabular}

${ }^{*}$ with the presumption that the entire sweet corn stover is available for recycling

${ }^{* *}$ on dry weight basis

Table 3 : Energy budgeting of different rice based cropping system under lowland situations of Goa (pooled mean of five years)

\begin{tabular}{lllllll}
\hline $\begin{array}{l}\text { Cropping } \\
\text { systems }\end{array}$ & $\begin{array}{l}\text { Total energy } \\
\text { input }\left(\mathbf{M J ~ h a}^{-1}\right)\end{array}$ & $\begin{array}{l}\text { Total energy } \\
\text { output }\left(\mathbf{M J ~ h a}^{-1}\right)\end{array}$ & $\begin{array}{l}\text { Energy use } \\
\text { efficiency }\end{array}$ & $\begin{array}{l}\text { Specific energy } \\
\mathbf{( M J ~ k g ~} \mathbf{~})^{-1}\end{array}$ & $\begin{array}{l}\text { Energy productivity } \\
\left.\mathbf{k g ~ M J}^{-1}\right)\end{array}$ & $\begin{array}{l}\text { Net energy } \\
\left(\mathbf{M J ~ h a}^{-1}\right)\end{array}$ \\
\hline Rice-fallow & 15682 & 79115 & 5.04 & 2.90 & 0.34 & 63433 \\
Rice-cowpea & 20836 & 102018 & 4.89 & 1.47 & 0.67 & 81181 \\
Rice-groundnut & 22113 & 107060 & 4.84 & 1.35 & 0.74 & 84946 \\
Rice-brinjal & 38332 & 302366 & 7.88 & 0.95 & 1.04 & 264034 \\
Rice-sweet corn & 23280 & 1082858 & 46.5 & 0.65 & 1.52 & 1059577 \\
\hline
\end{tabular}


Rice fallow could not involve much labour, thereby created very less employment opportunities (52 man-days ha ${ }^{-1}$ year ${ }^{-1}$ ). But when cropping intensity was increased through double cropping under rice fallow, the employment potential was increased substantially. The highest employment was generated in rice-brinjal system (217 man-days ha ${ }^{-1}$ year $^{-1}$ ) with an increase of $317 \%$ over mono-cropping (Table 4). The increased labour intensity in rice-brinjal cropping system involving additional work for crop production activities accounted for additional man-days and wages ( $₹ 54,250$ ha $^{-1}$ year ${ }^{-1}$ ) over rice fallow. It is worth noting here that the labour involvement in rice-brinjal system was spread out throughout the year. Similar study involving vegetable (okra) under rice fallow showed higher employment generation than the other systems under East coast conditions of India (Ray et al., 2016). Diversification and intensification of farming activities improved utilization of labour, reduced unemployment and provided a source of livelihood (Thamrongwarangkul, 2001; Van et al., 2003).

The data pertaining to the economics of different cropping systems are presented in Table 5. The cost of production was found higher in rice-brinjal ( $\left.₹ 70070 \mathrm{ha}^{-1}\right)$, whereas the highest net return was observed with rice-sweet corn system ( $\left.₹ 95350 \mathrm{ha}^{-1}\right)$. This indicated better economic efficiency of rice-sweet corn system due to higher crop equivalent yield and better market price. Net returns from rice-cowpea, rice-groundnut, rice-brinjal and rice-sweet corn were found to be $59.8,21.3,45.0$ and $63.2 \%$ higher than the rice-fallow, respectively. The benefit-cost ratio indicates the rate of return per rupee invested in a farm enterprise. Although the highest benefit-cost ratio was recorded with the rice-

Table 4 : Employment potential of rice based cropping systems under lowland situations of Goa (pooled mean of five years)

\begin{tabular}{|c|c|c|c|}
\hline Cropping systems & $\begin{array}{l}\text { Employment potential } \\
\text { (Man-days ha }^{-1} \text { year }^{-1} \text { ) }\end{array}$ & $\begin{array}{l}\text { Potential for wages } \\
\left(₹ \text { ha }^{-1} \text { year }^{-1}\right)\end{array}$ & $\begin{array}{l}\text { Per cent increase in wages } \\
\text { over rice-fallow system }\end{array}$ \\
\hline Rice-fallow & 52 & 13000 & -- \\
\hline Rice-cowpea & 146 & 36500 & 180.8 \\
\hline Rice-groundnut & 115 & 28750 & 121.1 \\
\hline Rice-brinjal & 217 & 54250 & 317.3 \\
\hline Rice-sweet corn & 172 & 43000 & 230.8 \\
\hline
\end{tabular}

*Labour wages are considered at ₹ 250/day

Table 5 : Economics of different rice based cropping systems under lowland situations of Goa

\begin{tabular}{llllll}
\hline $\begin{array}{l}\text { Cropping } \\
\text { systems }\end{array}$ & $\begin{array}{l}\text { Cost of production } \\
\left(\text { ₹ ha }^{-1}\right)\end{array}$ & $\begin{array}{l}\text { Net return } \\
\left(₹ \text { ha }^{-1}\right)\end{array}$ & $\begin{array}{l}\text { Benefit cost } \\
\text { ratio }\end{array}$ & $\begin{array}{l}\text { Economic } \\
\text { productivity } \\
\left(₹ \text { ha }^{-1} \text { day }^{-1}\right)\end{array}$ & $\begin{array}{l}\text { Profit over } \\
\text { rice-fallow } \\
\text { system (₹) }\end{array}$ \\
\hline Rice-fallow & 30350 & 58410 & 2.93 & 442.5 & - \\
Rice-cowpea & 51150 & 93350 & 2.83 & 393.9 & 34940 \\
Rice-groundnut & 57250 & 70870 & 2.24 & 257.8 & 12460 \\
Rice-brinjal & 70070 & 84670 & 2.21 & 307.9 & 26260 \\
Rice-sweet corn & 64950 & 95350 & 2.47 & 449.8 & 36940 \\
\hline
\end{tabular}

Table 6 : Soil fertility status of different cropping systems under lowland situations of Goa after five continuous cycles

\begin{tabular}{|c|c|c|c|c|c|}
\hline Cropping systems & $\mathrm{pH}$ & E.C $\left(\mathrm{dS} \mathrm{m} \mathrm{m}^{-1}\right)$ & $\begin{array}{l}\text { Available N } \\
\left(\mathrm{kg} \mathrm{ha}^{-1}\right)\end{array}$ & $\begin{array}{l}\text { Available } \mathrm{P}_{2} \mathrm{O}_{5} \\
\left(\mathrm{~kg} \mathrm{ha}^{-1}\right)\end{array}$ & $\begin{array}{l}\text { Available } \mathrm{K}_{2} \mathrm{O} \\
\left(\mathrm{kg} \mathrm{ha}^{-1}\right)\end{array}$ \\
\hline Initial status & 6.01 & Nil & 154.9 & 21.1 & 188.0 \\
\hline \multicolumn{6}{|c|}{ After five years of cropping } \\
\hline Rice-fallow & 5.57 & 0.049 & 173.1 & 32.7 & 158.2 \\
\hline Rice-cowpea & 5.47 & 0.037 & 179.2 & 37.8 & 164.7 \\
\hline Rice-groundnut & 5.69 & 0.053 & 162.4 & 32.5 & 146.7 \\
\hline Rice-brinjal & 5.42 & 0.068 & 166.1 & 24.7 & 184.7 \\
\hline Rice-sweet corn & 5.68 & 0.039 & 184.8 & 35.7 & 136.7 \\
\hline S.Em \pm & 0.05 & 0.008 & 9.41 & 3.24 & 13.49 \\
\hline C.D $(P=0.05)$ & 0.16 & NS & NS & NS & NS \\
\hline
\end{tabular}


fallow system (2.93), the rice-cowpea system recorded equally better benefit-cost ratio (2.83) owing to its lower cost of cultivation and higher net returns followed by rice-sweet corn system (2.47). Under similar situations of East coast of India, Ray et al. (2016) reported higher productivity, net returns, benefit: cost ratio and profitability in the rice-okra system and the lowest from rice-green gram system. Ramachandra et al. (2007) noticed higher net return with rice-marigold crop sequence (₹ $66573 \mathrm{ha}^{-1}$ ) followed by rice-bell pepper system ( $\left.₹ 62,283 \mathrm{ha}^{-1}\right)$.

The fertility of soil after each crop cycle was evaluated and the results showed significant changes in soil pH in all the cropping systems compared to the initial status. Continuous cropping of brinjal (5.42) and cowpea (5.47) after rice for five years in fixed plot found to reduce the soil pH significantly as compared to initial status (6.01). This decrease may be attributed to the addition of higher quantity of acid forming fertilizers in ricebrinjal; leaf fall and its subsequent decomposition in rice-cowpea system. It is pertinent to note that the soil pH in rice-sweet corn (5.68) and rice-groundnut (5.69) were relatively higher than rice fallow (5.57) systems after five years of cropping in fixed plots. Ali et al. (2012) also observed that inclusion of leguminous crops in the rice-wheat system lowered the soil pH. Balanced nutrition and inclusion of legume crops in cereal based cropping system will provide feasible soil environment for plant growth especially by reducing the soil pH with improved nutrient uptake (Singh et al., 2013; Singh et al., 2014).

After five crop cycles, although the NPK buildup of the soil was insignificant, $\mathrm{N}$ and $\mathrm{P}$ balances were positive (Table 7), while $\mathrm{K}$ balances were found negative in all the cropping systems. This indicated that the $\mathrm{K}$ fertilizer recommendations were insufficient to meet the crop requirement. But, the magnitude of negative balance was lower in rice-brinjal ( $184.7 \mathrm{~kg} \mathrm{ha}^{-1}$ ) in contrast to ricesweet corn system which depicted a higher negative balance for $\mathrm{K}\left(136.7 \mathrm{~kg} \mathrm{ha}^{-1}\right)$ over the initial status $\left(188 \mathrm{~kg} \mathrm{ha}^{-1}\right)$. This difference may be attributed to the removal of more $\mathrm{K}$ with the significantly higher biomass produced in the rice-sweet corn system (Singh et al., 2011). Parmar et al. (2016) reported higher depletion of $\mathrm{K}$ with inclusion of vegetable (potato), oilseed (rapeseed) and pulse (mung bean) in rice-based cropping systems compared to rice-wheat system after three cycles of cropping. Further, balanced nutrition in these cropping systems helped to achieve positive balance of $\mathrm{N}$ and $\mathrm{P}$ and negative $\mathrm{K}$ balance was reduced. In another study, balanced nutrition helped in achieving positive nutrient balance of $\mathrm{P}$ and $\mathrm{K}$ under different cropping systems (Rajkhowa et al., 2017). This result reveals that use of balanced nutrition plays a major role in sustaining the productivity of cropping systems.

From this study, it can be concluded that rice-sweet corn system was the most productive, economical and energy efficient cropping system for the West coast region of India under protective irrigated conditions. However, under residual soil moisture situations of rice fallows, cultivation of cowpea would be more economical than the cultivation of rice alone in Kharif under lowland areas of the region for higher profitability and soil sustainability.

\section{Acknowledgments}

The authors are thankful to the Indian Council of Agricultural research, New Delhi and ICAR-IIFSR, Modipuram for providing financial support to carry out the research.

\section{References}

Ali, R.I., T.H. Awan, M.M. Ahmad, U. Saleem and M. Akhtar: Diversification of rice-based cropping systems to improve soil fertility, sustainable productivity and economics. J. Anim. Plant Sci., 22, 108-112 (2012).

Anjaneyulu, V. R., S. P. Singh and M. Pal: Effect of competition free period and technique and pattern of pearl millet planting for growth and yield of mungbean and total productivity in soil for pearl millet and pearl millet/ mungbean intercropping system. Indian J. Agron., 27, 219-226 (1982).

Basak, N., A. Datta, T. Mitran, B. Mandal and P.K. Mani: Impact of organic and mineral inputs onto soil biological and metabolic activities under a long-term rice-wheat cropping system in sub-tropical Indian Inceptisol. J. Environ. Biol., 37, 83-89 (2016).

Brahmanand, P.S., B.C. Ghosh and N. Sahoo: Effect of organic and inorganic sources of nitrogen on productivity of rice in rice-fish farming system. Arch. Agron. Soil Sci., 55, 663-670 (2009).

Bray, R.H. and L.T. Kurtz: Determination of total, organic and available forms of phosphorus in soils. Soil Sci., 59, 39-45 (1945).

Choudhary, J.B., R.G. Thakur, M. Bhargav and R.D. Sood: Production potential and economics of maize (Zea mays)-based crop sequences on farmers field. Indian J. Agron., 45, 232-235 (2000).

Gill, M.S. and I.P.S. Ahlawat: Crop diversification-its role towards sustainability and profitability. Indian J. Fertil., 2, 125 (2006).

Hanway, J.J. and H. Heidel: Soil analysis method as used in lowa State College, Soil Testing Laboratory. lowa Agri., 54, 1-31 (1952).

Hegde, D.M., T.S. Prakash and M. Rai: Crop diversification in Indian Agriculture. Agric. Situat. India, 351-354 (2003).

Kankwamba, H., M. Mapila and K. Pauw: Determinants and spatiotemporal dimensions of crop diversification in Malawi. Proj. Rep. Prod. under a co-financed Res. Agreem. between Irish Aid, USAID IFPRI, Pap (2012).

Kannan, R.L., M. Dhivya, D. Abinaya, R.L. Krishna and S. Krishnakumar: Effect of integrated nutrient management on soil fertility and productivity in maize. Bull. Env. Pharmacol. Life Sci., 2, 61-67 (2013).

Knoth, J.L., S.H. Kim, G.J. Ettl and S.L. Doty: Biological nitrogen fixation and biomass accumulation within poplar clones as a result of inoculations with diazotrophic endophyte consortia. New Phytologist, 201, 599-609 (2014).

Korikanthimath, V.S. and B.L. Manjunath: Integrated farming systems for sustainability in agricultural production. Indian J. Agron., 54, 140-148 (2009).

Manjunath, B.L. and C.J. Itnal: Energy input and output relationship in rice based cropping systems. Madras Agric. J., 92, 84-88 (2005).

Manjunath, B.L. and V.S. Korikanthimath: Productivity under different rice-based cropping systems and physio-chemical properties of 
soil as influenced by source of manure in coastal eco-system of Goa. J. Farming Res. Dev., 10, 33-40 (2004).

Manjunath, B.L. and V.S. Korikanthimath: Sustainable rice production through farming systems approach. J. Sust. Agri., 33, 272-284 (2009).

Manjunath, B.L., H.R.P. Desai, R. Ramesh, J.R. Faleiro and N.P. Singh: Rice based cropping/farming systems for higher productivity and profitability. Technical Bulletin No: 22, ICAR, Goa, India (2010).

Parmar, D.K., D.R. Thakur, R.S. Jamwal and Arpana: Effect of long term organic manure application on soil properties, carbon sequestration, soil-plant carbon stock and productivity under two vegetable production system in Himachal Pradesh. J. Environ. Biol., 37, 333-339 (2016).

Pokhrel, S. and S. Pokhrel: Legumes crop rotation can improve food and nutrition security in Nepal. Agron. J. Nepal, 3, 123-127 (2013).

Rafiee, S., S.H.M. Avval and A. Mohammadi: Modeling and sensitivity analysis of energy inputs for apple production in Iran. Energy, 35, 3301-3306 (2010).

Rajkhowa, D.J., A.K. Sarma, K. Mahanta, U.S. Saikia and R. Krishnappa: Effect of vermicompost on greengram productivity and soil health under hilly ecosystem of North East India. J. Environ. Biol., 38, 1519 (2017).

Ramachandra, C., M.S. Anwarulla, G. Janardhan and P. Murthy: Production potential and economics of rice-based cropping systems in hill zone of Karnataka, India. Int. J. Agric. Sci., 3, 127129 (2007).

Ray, M., D.C. Roy and A. Zaman: Evaluation of rice (Oryza sativa)-based cropping systems for increasing productivity, resource-use efficiency and energy productivity in coastal West Bengal. Indian J. Agron., 61, 131-137 (2016).

SAS Institute: SAS 9.4 Output Delivery System: User's Guide. SAS Institute (2014).

Sharma, R.P., S.K. Dutta and M. Ghosh: Diversification of rice (Oryza sativa)-wheat (Triticum aestivum) cropping system for sustainable production in south Bihar alluvial plains. Indian J. Agron., 59, 191-199 (2014).

Singh, A.K., M.K. Meena, R.C. Bharati and R.M. Gade: Effect of sulphur and zinc management on yield, nutrient uptake, changes in soil fertility and economics in rice (Oryza sativa)-lentil (Lens culinaris) cropping system. Indian J. Agril. Sci., 83, 344-348 (2013).

Singh, R.K., J.S. Bohra, T. Nath, Y. Singh and K. Singh: Integrated assessment of diversification of rice-wheat cropping system in Indo-Gangetic plain. Arch. Agron. Soil Sci., 57, 489-506 (2011).

Singh, S.S., A.K. Singh and P.K. Sundaram: Agrotechnological options for upscaling agricultural productivity in Eastern Indo Gangetic plains under impending climate change situations: A review. J. Agrisearch, 1, 55-65 (2014).

Subbiah, B.V. and G.L. Asija: A rapid procedure for determination of available nitrogen in soils. Curr. Sci., 25, 259-260 (1956).

Thamrongwarangkul, A.: Annual report on sustainable community development for good livelihoods and environmental project. Khon Kaen University, Thailand (2001).

Van, M.L., E.J. Morales, D. Turingruang and D.C. Little: Livelihood improving functions of pond based integrated agriculture and aquaculture systems. MRC Fisheries Programme (FP). Institute of Aquaculture, University of Stirling, Scotland, UK (2003). 